\title{
Plants used in traditional medicine in the Comoros archipelago. A review
}

\author{
Matthew Saive ${ }^{(1)}$, Michel Frederich ${ }^{(2)}$, Marie-Laure Fauconnier ${ }^{(1)}$ \\ (1) University of Liège - Gembloux Agro-Bio Tech. Laboratory of Chemistry of Natural Molecules. Passage des Déportés, 2. \\ BE-5030 Gembloux (Belgium).E-mail: msaive@student.uliege.be \\ (2) University of Liège. Department of Pharmacognosy. Liège (Belgium).
}

Received 23 June 2019, accepted 1 april 2020, available online 22 April 2020.

This article is distributed under the terms and conditions of the CC-BY License (http://creativecommons.org/licenses/by/4.0)

Introduction. In the Comoros archipelago, as in many places in Africa, traditional medicine is the first reflex people have when it comes to finding a cure. This work illustrates the diversity of remedies found in this group of islands. The plant species potentially effective from a pharmaceutical point of view can be targeted through the comparison of different databases. The present study also illustrates the importance of preventing the loss of traditional knowledge based on hundreds of years of observations.

Literature. The information in this paper originates from databases built by ethnobotanists as well as peer reviewed scientific articles. In addition, some information also come from work done by locals working with recognized organisms.

Conclusions. The scientific literature cites 207 different species that are used for traditional practices in the Comoros archipelago, among which 9 are endemic. These species were compared to the pharmacopoeias of other islands and surroundings from the Indian Ocean in terms of similarities and differences between targeted ailments. Only 3\% of the cited species present similarities in use among the islands of the Indian Ocean and surroundings.

Keywords. Traditional medicines, ethnobotany, Indian Ocean, Comoros.

\section{Les plantes utilisées en médecine traditionnelle dans l'archipel des Comores (synthèse bibliographique)}

Introduction. Dans l'archipel des Comores, comme dans de nombreuses régions d'Afrique, le premier réflexe adopté par les populations quand il s'agit de se soigner est la médecine traditionnelle. Ce travail illustre la diversité des remèdes à base de plantes que l'on retrouve dans cette région du monde. C'est à l'aide de travaux similaires à celui-ci que des espèces potentiellement intéressantes pour le monde pharmaceutique et cosmétique peuvent être identifiées. De plus, ce type d'étude contribue à la préservation d'un savoir ancestral en voie de disparition.

Littérature. Les informations mentionnées dans ce travail sont issues de bases de données construites par des ethnobotanistes ainsi que d'articles scientifiques validés par les pairs. Une partie des données proviennent aussi de travaux réalisés par des locaux en collaboration avec des organismes reconnus.

Conclusions. La littérature scientifique concernant la pharmacopée traditionnelle de l'archipel des Comores cite 207 espèces différentes. Parmi ces espèces, 9 sont endémiques de l'archipel. La totalité des espèces a été comparée aux autres iles de l'océan Indien ainsi qu'aux régions avoisinantes du point de vue des usages respectifs. À l'issue de ce travail, il s'avère que seulement $3 \%$ de ces espèces sont utilisées de manières similaires dans ces différentes régions.

Mots-clés. Médicament traditionnel, ethnobotanique, océan Indien, Comores.

\section{INTRODUCTION}

As long as humankind can remember, plants have been part of Human's development. In addition to the management of the carbon equilibrium, they can be a source of food, medicine, cosmetics, fabric, energy, as well as of construction materials (Cartier, 1994; Bouloc, 2006; Hoffman et al., 2007; Soidrou et al.,
2013; Rakotoniaina et al., 2018). The earliest records of plant use for medicine, among other habits and beliefs, were found in ancient Egypt and are estimated to date from $2500 \mathrm{BCE}$ (Kelly, 2009). Even though the way plants are used has been changing, their use is still a common practice nowadays. In the $19^{\text {th }}$ century, as science and medicine progressed, traditional uses of plants in medicine provided an ever-growing source 
of inspiration for the development of new drugs and treatments (Farnsworth, 1966; Heitzman et al., 2005; Katiyar et al., 2012), starting with the isolation of morphine from Papaver somniferum L. by Friedrich Sertüner in 1806 (Brownstein, 1993).

These discoveries were the early stages of what would become the birth of ethnopharmacology in 1967 (Heinrich, 2015). This field of study is defined as "the interdisciplinary scientific exploration of biologically active agents traditionally employed or observed by man, putting in relation plants, fungi, animals, microorganisms, minerals, the way people use them and the biological and pharmacological effects of those ingredients. It is a discipline tightly linked to ethnobotany and phytochemistry" (Holmstedt, 1991). The ethnobotanical part of this discipline led to the gathering of huge amounts of data. In order to simplify the access to that immense source of knowledge, ethnobotanists have been creating many very complete databases such as: NAPRALERT (United States of America); PHARMEL (Belgium); PRELUDE (Belgium); PROTA (The Netherlands); Kew MPNS (Great Britain); MNHN (France). These databases contain information that can prove very interesting for laboratory scientists in order to target the species on which detailed analyses should be implemented (Farnsworth, 1994).

Ethnobotany has proven to be effective for the discovery of important medicine: e.g. in Madagascar, Catharanthus roseus (L.) G.Don has been used traditionally to treat many pathologies, such as pancreatic pain, colitis, chest pain, heartburn and gastritis (Razafindraibe et al., 2013; Randriamiharisoa et al., 2015). Phytochemical studies were conducted on this species and led to the discovery of many alkaloids such as vindoline I, vindolidine II, vindolicine III, vindolinine IV as well as vinblastine and vincristine. Among these alkaloids some are used nowadays as anti-cancer drugs in modern medicine (Tiong et al., 2013; Dugé de Bernonville et al., 2015). Other plants, originating from different places have been subject to similar investigations and led to the discovery of interesting new compounds. As an example, in the Reunion Island, Centella asiatica (L.) Urb. is used traditionally to treat many benign and malignant ailments (e.g. aspergillosis, scabies, fungal infections). After a phytochemical study was undertaken, compounds such as asiaticoside, brahmoside, brahminoside or kaempferol were identified (Hashim et al., 2011). Thus, C. asiatica was proven to be useful against serious immune disorder diseases. Even though not all compounds and mechanisms have been investigated and studied in depth, this species is currently used as an ingredient in patented phytomedicines (Rangel, 2009).

The two species mentioned above come from places known for their wide biodiversity, which are called biodiversity hotspots. The Indian Ocean is home to many biodiversity hotspots as $25 \%$ of the world's biodiversity can be found there, as well as in subsaharan Africa (Gurib Fakim, 2011).

Among the large number of different species found in the western part of the Indian Ocean, many are endemic. Mauritius, Réunion, Rodrigues, Seychelles, the Comoros archipelago and Madagascar together are home to 11 endemic plant families, including at least 310 endemic genera, leading to a total of around 10,000 endemic species (Rasoanaivo, 2011).

While several studies on Madagascar, Reunion Island, Mauritius and Rodrigues review current knowledge in ethnobotany in these areas, it is surprising to note that despite the incredible potential of the Comoros archipelago, no study has been devoted to them.

People from the Comoros archipelago live in rural areas. Poverty and difficult access to a modern health care system have led them to develop their own health system based on natural products. The cultural background of these people, being a mix of African Bantu and Arab-Muslim, gave to this region of the world a diversified and rich knowledge when it comes to traditional medicine. The conservation of this knowledge is based on an oral transmission from one generation to the next (Kaou et al., 2008; Soidrou et al., 2013).

We thus focused on this part of the world in this work for the previously mentioned reasons, that are:

- it is known as a biodiversity hotspot and the birthplace for many different species (Tatayah, 2011);

- due to its location, it has had the cultural influences of many ethnicities (Kaou et al., 2008; Soidrou et al., 2013);

- lastly, only very little data compilation has been done on the botanicals used in traditional medicine in this part of the world.

Mainly peer reviewed documents were taken into account and most of the ethnobotanical information can be linked to one or several vouchers stored in herbaria. As some work was done by locals, in collaboration with a recognized botanic conservatory (CBNM Conservatoire botanique national de Mascarin), these data were also taken into account.

In the end, this work has led to the creation of an exhaustive list of plant species and their traditional uses, based on all available and significant literature. The perspective of development, risks and limitations linked to the use of plants from the Comoros archipelago in traditional medicine are also discussed.

To find the information mentioned in this article, systematic bibliographic research was conducted in the PRELUDE database as well as in Google Scholar. As the first database already targets ethnobotanical 
information the keyword used was Comores. The keywords used to do the research in Google Scholar were the following: Comoros archipelago, Moheli, Mwali, Mayotte, Maore, Anjouan, Ndzuwani, Grande Comore, Nagzidja linked to ethnobotany, traditional practices, traditional medicine, cosmetics. This process led to the identification of 100 bibliographic references.

\section{CONTEXT AND STUDY AREA}

In a context where exports equal a tenth of the imports (13,8 M \$ versus 129,6 M \$) in 2007 (UNCTAD, 2011), it is crucial to find new ways to finance the region. One way to reach that goal is to seek high added values in available goods. In this case, the rich and diverse flora of the archipelago has been targeted. As mentioned by El Hilaly et al. (2003) and Mhame (2004), folk medicine can be an asset helping the financial status of a region. Through the discovery of valuable plant species for the pharmaceutical and cosmetic business, the import and export balance could be influenced towards a healthier situation. It is vital for the exploitation of these goods to be carried out in a sustainable manner or else this type of work cannot guarantee solid change in the long term (Abdurazag et al., 2003).

\subsection{Geography and climate}

The Comoros archipelago lies in the northern region of the Mozambique Channel. It is composed of four main islands, respectively Grande Comore $\left(950 \mathrm{~km}^{2}\right)$, Anjouan $\left(378 \mathrm{~km}^{2}\right)$, Mayotte $\left(370 \mathrm{~km}^{2}\right)$ and Mohéli $\left(216 \mathrm{~km}^{2}\right)$. In addition, around 60 islets are found in the surrounding seas, especially south of Mohéli and in the Mahoran lagoon. The archipelago is the result of the separation of the Malagasy and African plates, between the Miocene and the late Pleistocene, which led to the creation of this volcanic pack of islands (Nougier et al., 1986). Due to their volcanic origin, these islands present a hilly landscape with summits reaching 2,361 m (Mount Karthala) for Grande Comore, 1,595 m (Mount Ntringui) for Anjouan, 790 m (Mzé Koukoulé) for Moheli and 660 m (Mount Benara) for Mayotte (Quod et al., 2000). The climate is tropical, with a hot and rainy season from December to April, during which the monsoon prevails and is characterized by an average temperature reaching $27^{\circ} \mathrm{C}$ during the day. The dry season starts in May and ends in November, with an average temperature reaching $23{ }^{\circ} \mathrm{C}$ during the day. The pluviometry of the different islands is strongly influenced by their relief as clouds tend to form and stay in places with high altitudes. On mount Karthala, rainfall can reach up to $5,000 \mathrm{~mm}$ per year, whereas the average yearly pluviometry of Moroni (located west of Anjouan Island, near the sea) only reaches $2,700 \mathrm{~mm}$ per year. The average pluviometry of Moheli, Grande Comore and Mayotte reach respectively 2,100 mm, 2,300 mm and 1,250 $\mathrm{mm}$ per year (OMM, 2018). Differences in pluviometry can also vary within the islands: e.g. in Mayotte, the south of the island measures rainfall below $1,300 \mathrm{~mm}$ per year and the north of the island regularly records rainfall reaching more than $2,000 \mathrm{~mm}$ per year (Boullet, 2016). All these characteristics within the archipelago and within the different islands are some of the reasons for the wide biodiversity (Rasoanaivo, 2011).

\subsection{Flora}

The flora of the Comoros archipelago has not been studied in depth, in opposition to other islands in the Indian Ocean (Morat \& Lowry, 1997; Pascal et al., 2001; Pascal, 2002). Floristic studies of the Comoros archipelago began in the first part of the $20^{\text {th }}$ century, when Voeltskow published "Flora und Fauna der Komoren. Reise in Ostafrika in den Jahren 1902-1905" (Vos, 2004) in which he identified 935 vascular plant species, including 416 endemic species. His work was completed by a more recent project aiming to identify the flora of the Comoros archipelago. The main studies made in Comoros were carried out by Moinjoin in 1981, Adjanohoun in 1982 and the PLARM (study of the characteristics and composition of aromatique and medicinal plants) project (Adjanohoun et al., 1982; Gurib Fakim \& Guého, 1999). More recently, studies of Kaou et al. and Soidrou et al. were added to this list (Kaou et al., 2008; Soidrou et al., 2013). The latest botanical studies for the Comoros archipelago estimate the number of species as being over 2,000 (indigenous and introduced) (Adjanohoun et al., 1982; Pascal, 2002; Barthelat \& Boullet, 2005; Barthelat \& Viscardi, 2012).

\section{METHODS}

Targeting significant literature to provide valuable data for those who will use it afterwards is of paramount importance. Likewise, we must highlight that within the identified posology mentioned in the literature, some remedies are more strongly linked to rites than to biological material, which calls for a cautious review on how the species are used. The ideal criteria in the ethnobotanical literature are, according to Trotter \& Logan (1986), as follows: the database should be significant, the scope should be comparable and complete, the plant specimens must be properly identified, vouchers need to be stored for further verification and, if possible, activity tests in 
the field should have been carried out so as to prove the potency of the concerned remedy. Considering how little ethnobotanical work has been done in the Comoros archipelago, only a few articles meet the criteria mentioned above. Therefore, the selected data originate from peer reviewed articles or from work done by recognized organizations such as the Conservatoire botanique national de Mascarin (CBNM) in collaboration with local inhabitants.

In fine, the data collected consist of the family name, the scientific name, the endemism of the plant as well as the targeted ailment and the part of the plant used when available (Table 1). The collected data were then studied so as to identify any type of consensus on the way the species were used in the Comoros and in the surrounding islands.

Based on the work carried out on the collected information, it was observed that in the Comoros archipelago, as well as in the other islands of the Indian Ocean, the number of uses per species varies widely. As this phenomenon was observed worldwide by many ethnobotanists, several data reduction tools have been developed to enhance the significance of the work. First to develop these tools were Trotter \& Logan in 1986, then Prance et al. (1987) mentioned the concept of quantitative ethnobotany. Following on from this, many researchers have used different approaches towards developing the significance of the data they have collected. Most indicators require information such as the number of informants, number of ailments per species, number of mentions for each species or treatment; this type of information is found when doing in field observations. As this work is a review, only the body system impacted and the number of health issues targeted per species were available, leading to the selection of the indicators as follows.

Considering these elements, the RII (Relative Importance Index) was established for each species using the work of Bennett \& Prance (2000). This indicator reflects the versatility of a species based on the normalized number of pharmacological properties and the normalized number of body (BS) systems it affects, using the following formula:

$$
R I I=\frac{B S_{T}}{B S_{S}}+\frac{H I_{S}}{H I_{M}} \times 50
$$

where $\mathrm{BS}_{\mathrm{T}}=$ total number of body system as mentioned in the literature (12) (Bennett \& Prance, 2000), $\mathrm{BS}_{\mathrm{S}}=$ body system specifically targeted by the concerned species, $\mathrm{HI}_{\mathrm{S}}=$ number of health issues claimed to be managed by a specific species, $\mathrm{HI}_{\mathrm{M}}=$ maximal number of health issues claimed to be managed by a specific species within this data set.

In 2003, as explained by Tardío \& Pardo de Santayana (2008), Pardo de Santayana developed a new indicator also called Relative Importance Index (RI). Similar to the RII mentioned previously, it is based on the relative number of use-categories (RNU); however, it does not take the body systems into account, rather it integrates the relative frequency of citation (RFC). In this present work, it is not possible to determine the RFC as there is no survey linked to the data in table 1 (Tardío \& Pardo de Santayana, 2008). On its own, the RNU can be considered as an indicator of the type of ailment that is more of a concern for the inhabitants of the archipelago. All the ailments mentioned in table 1 were sorted into 86 uses (data not shown); then the following formula was applied to the data set:

$$
R N U=\frac{N U_{S}}{N U_{\max }} \times 100
$$

where $\mathrm{NU}_{\mathrm{s}}=$ number of mentions of a specific use, $\mathrm{NU}_{\max }=$ maximum number of specific uses mentioned within the whole data set.

\section{DATA COLLECTION}

All the collected data have been gathered in table 1. A total of 207 different species from 80 different families have been mentioned in the literature, when it comes to the traditional use of plants of the Comoros archipelago. Among these families, the most frequently found are Fabaceae (9\%), Asteraceae (7\%), Euphorbiaceae (5\%), and Malvaceae (5\%) (Table 1).

When applying the two different indicators on the data in table 1, the following information stand out. Leptadenia madagascariensis Decne. and Ocimum canum Sims. both affect 7 body systems, however, L. madagascariensis is claimed to treat 7 health issues, giving a RII of 41.67 where $O$. canum is claimed to treat 19 different health issues, leading to a RII of 63.10. Ergo the latter is more versatile and could be studied in many different contexts. For our data set, the highest value, the average and the lowest values are respectively: 100 for Bidens pilosa L., 18.9 for the average and 1.79 for Canaga odorata (Lam.) Hook.F. \& Thomson, Struchium sparganophorum (L.) Kuntze, Commelina africana L., Acacia farnesiana (L.) Willd., Chrysopogon zizanioides (L.) Roberty and Cestrum nocturnum L. The common link between the 6 very low RII species resides in the fact that they are only used for cosmetics and therefore do not impact body systems. Based on this indicator, the plants to be targeted in further studies could be: B. pilosa, Kalanchoe pinnata (Lam.) Pers., Adansonia digitata L., Cassia occidentalis L. and all locally available Aloe species. These plants have in common the fact that they are used traditionally for many different ailments targeting many body systems, thereby enhancing the chances of having some significant biological activity. 


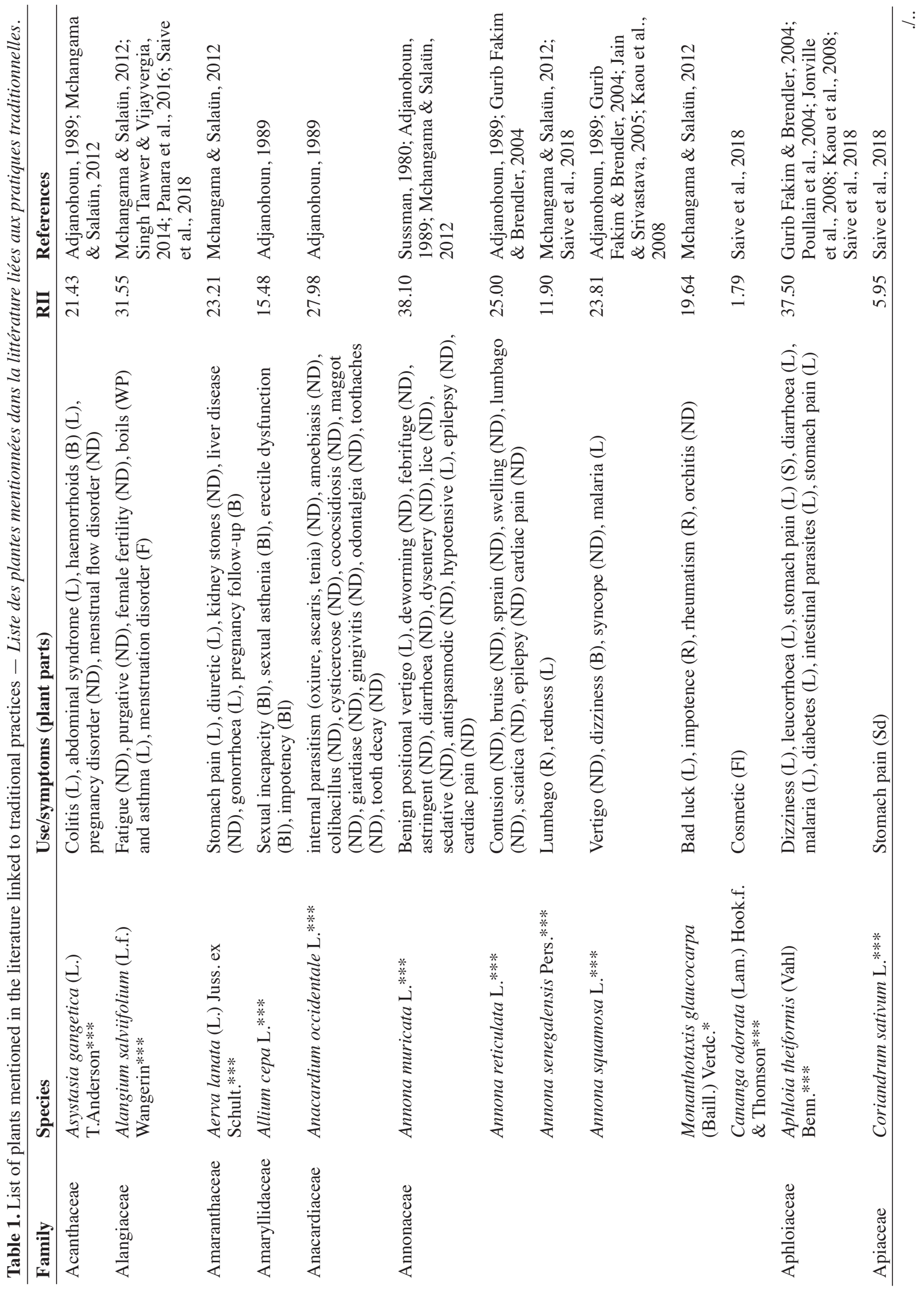




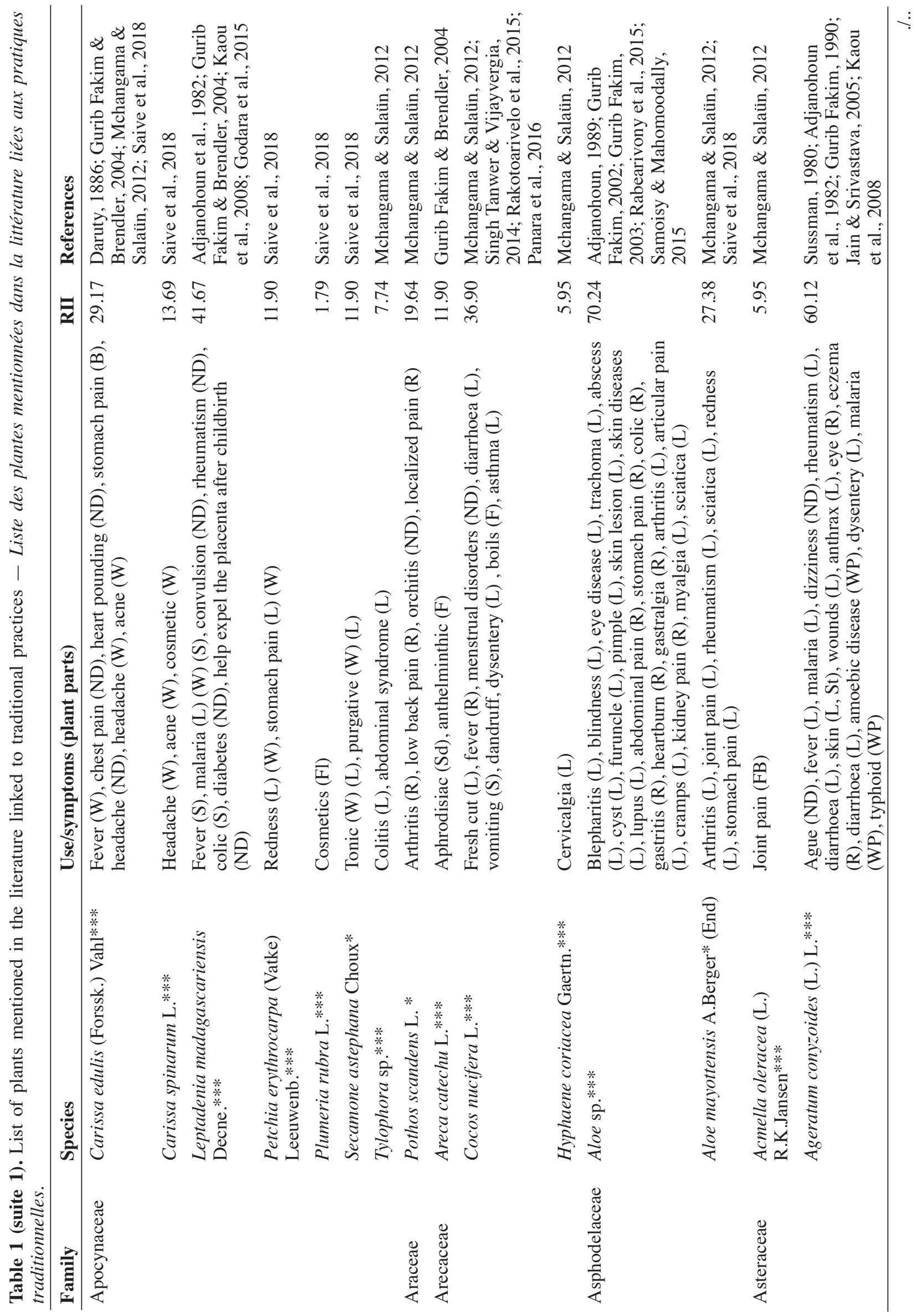


Ethnopharmacology in the Comoros archipelago

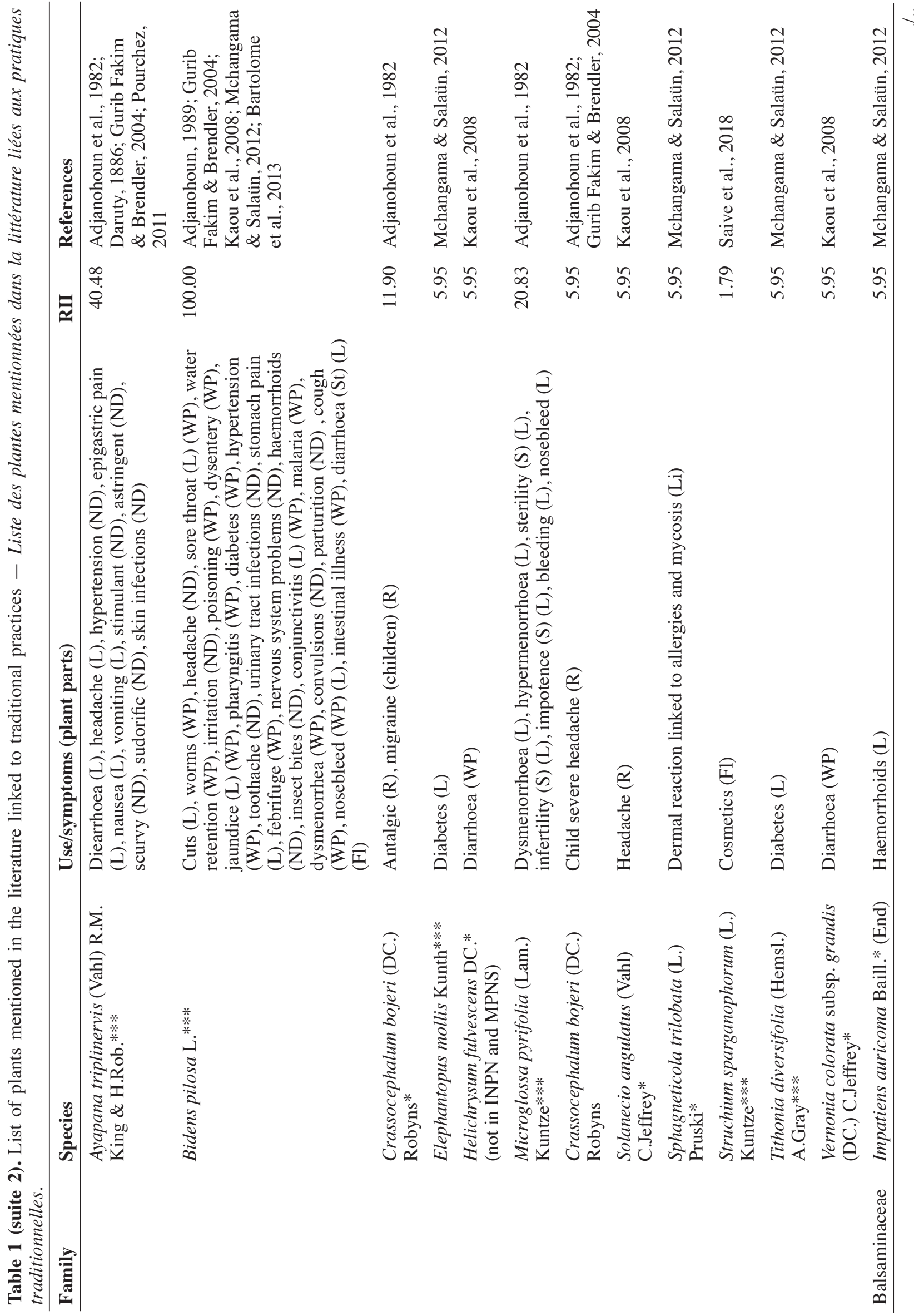




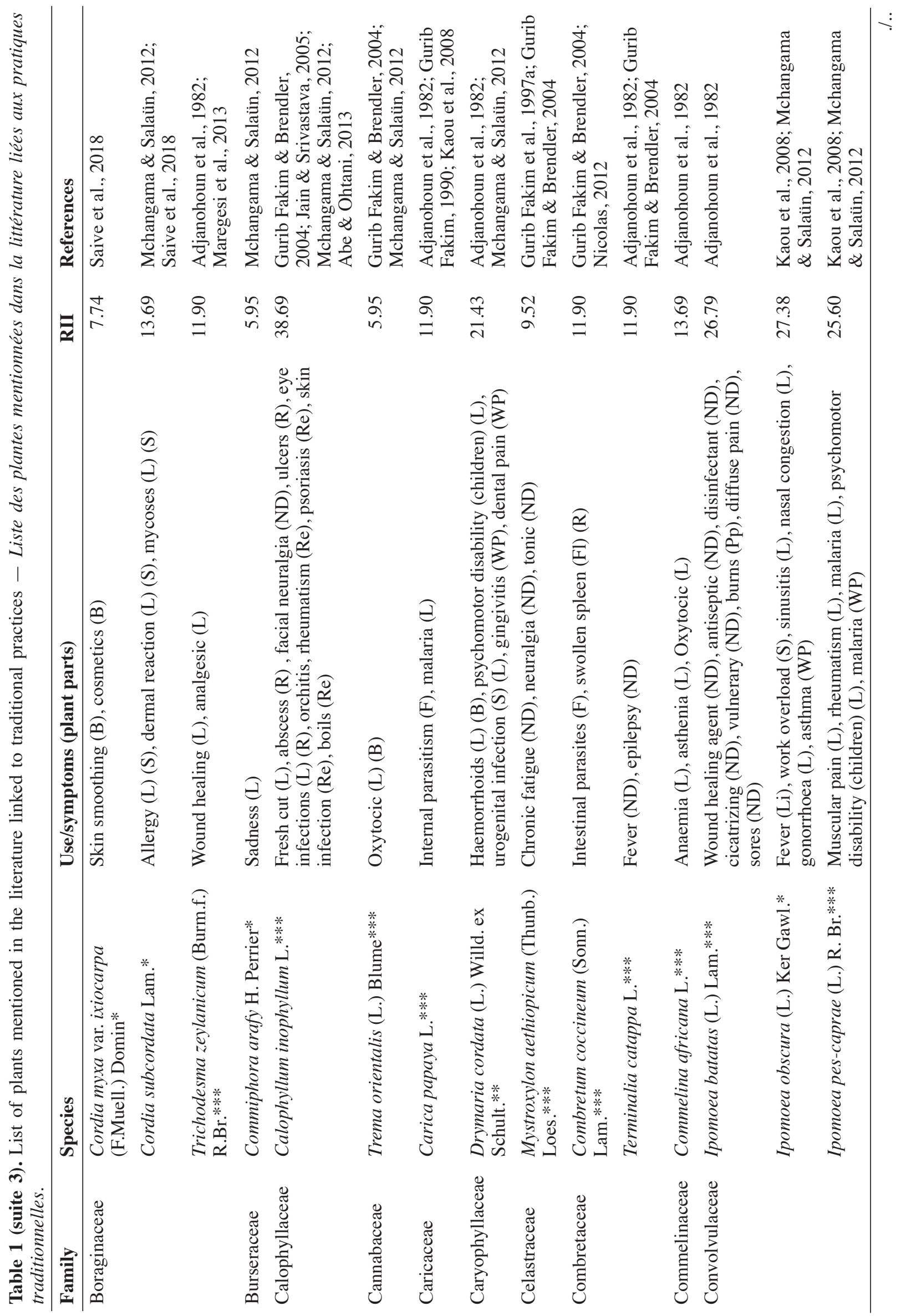




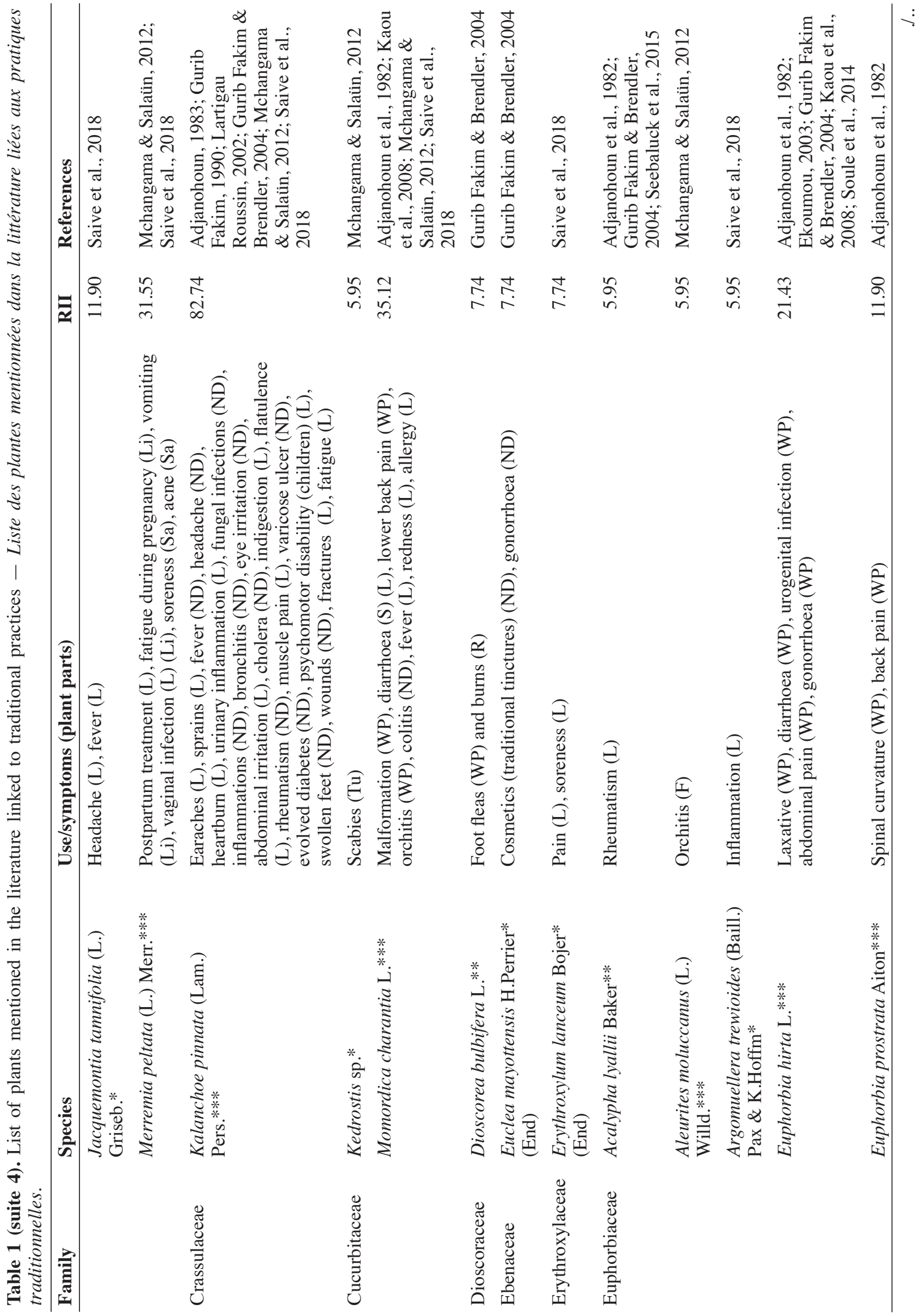




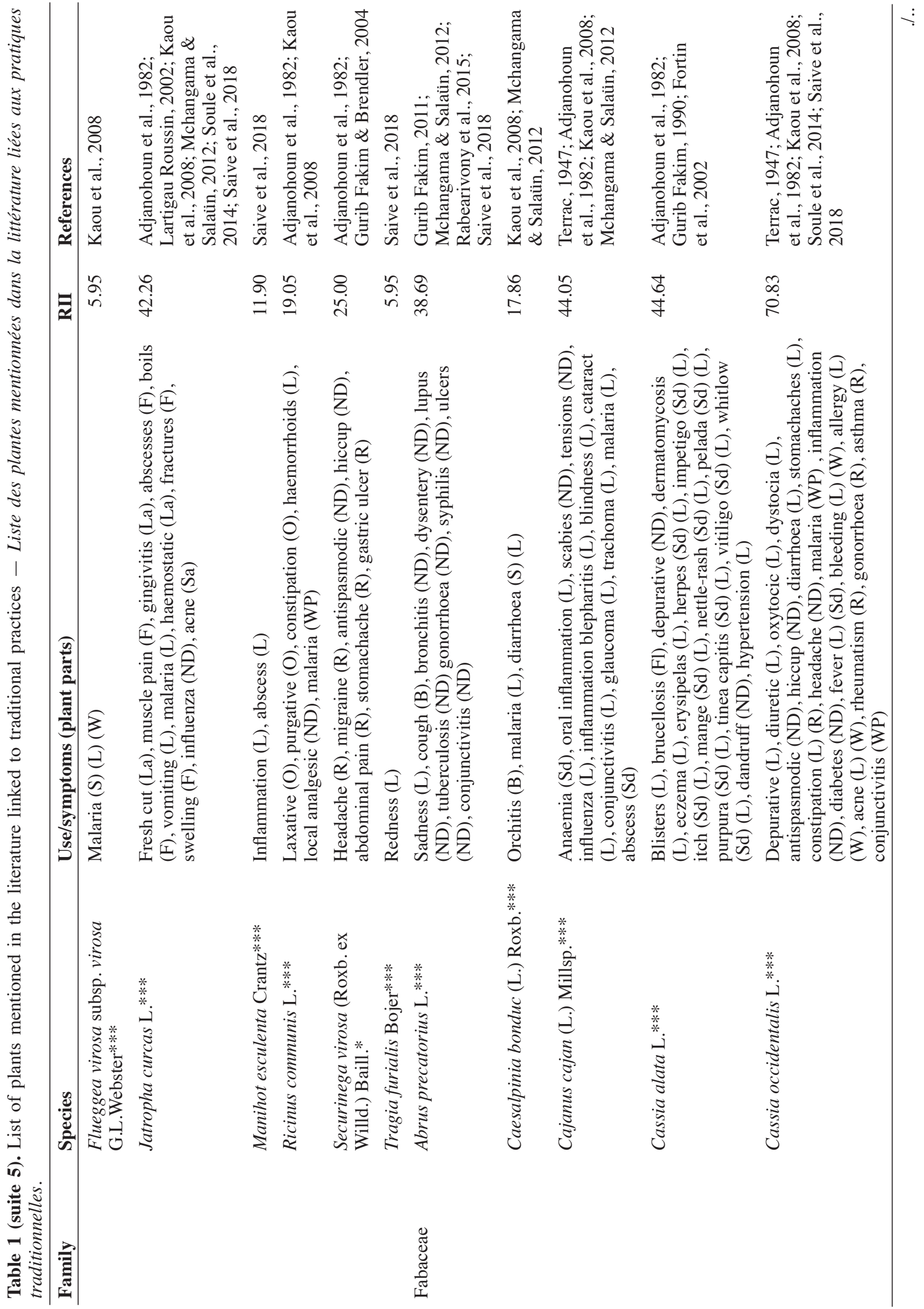




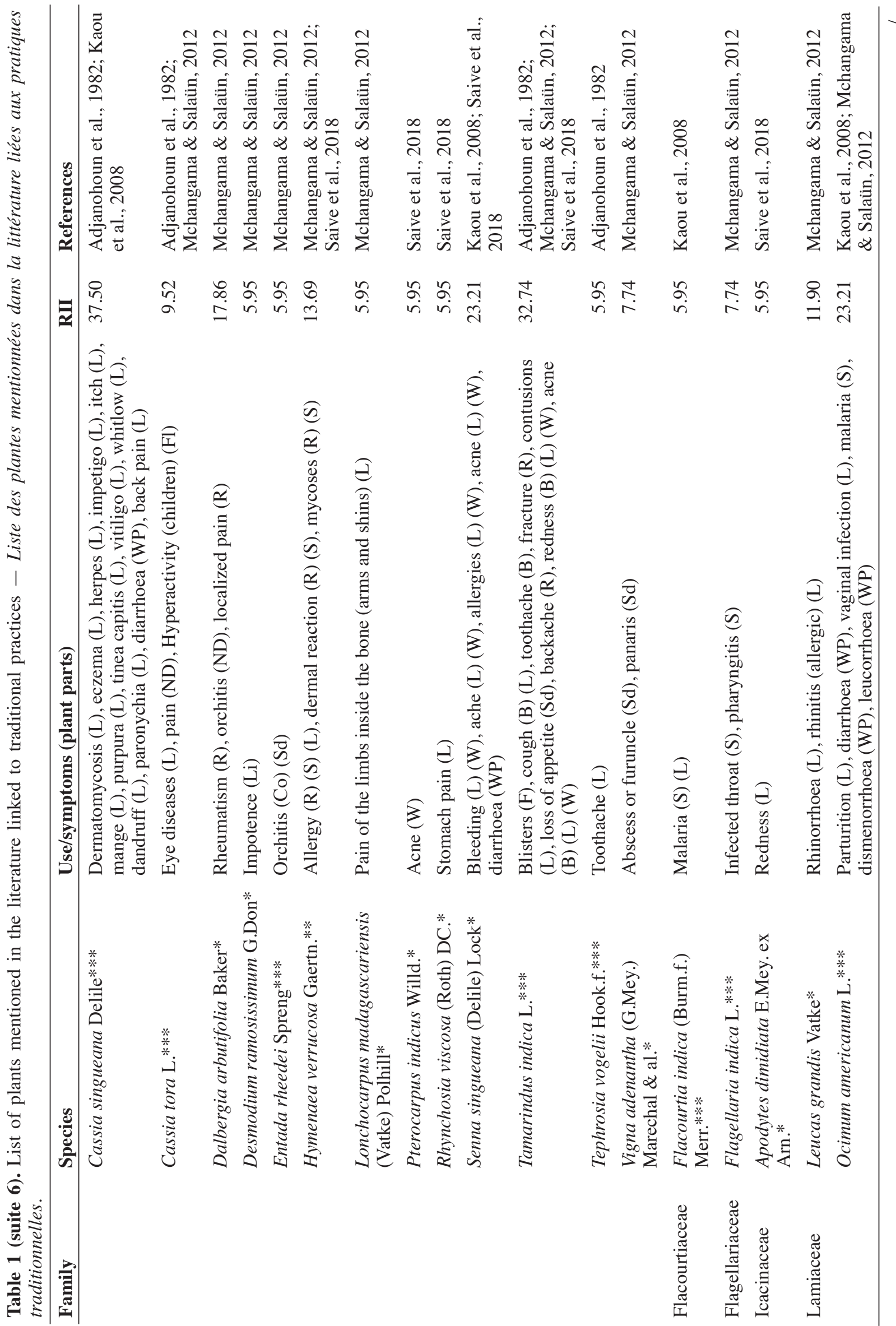




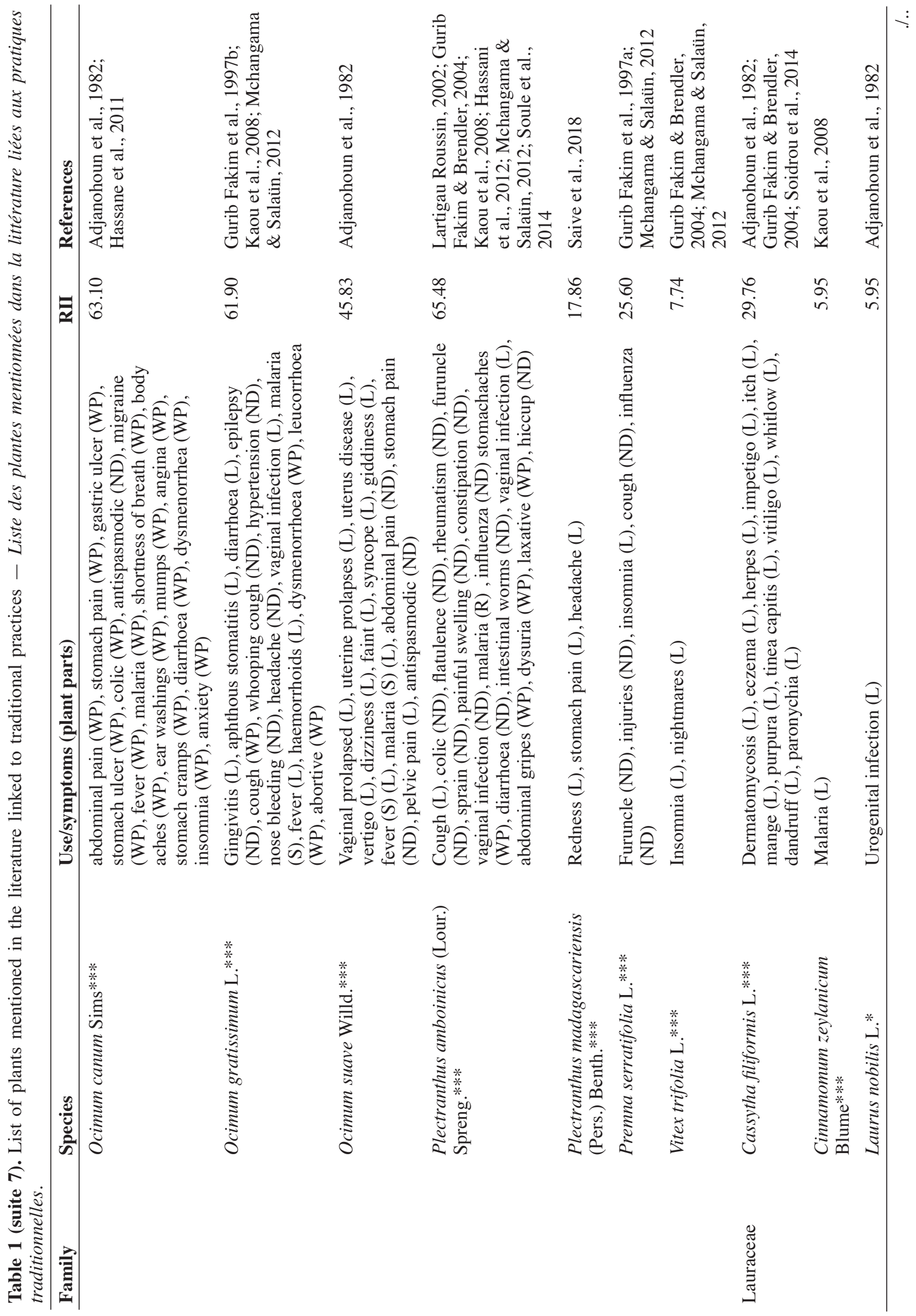




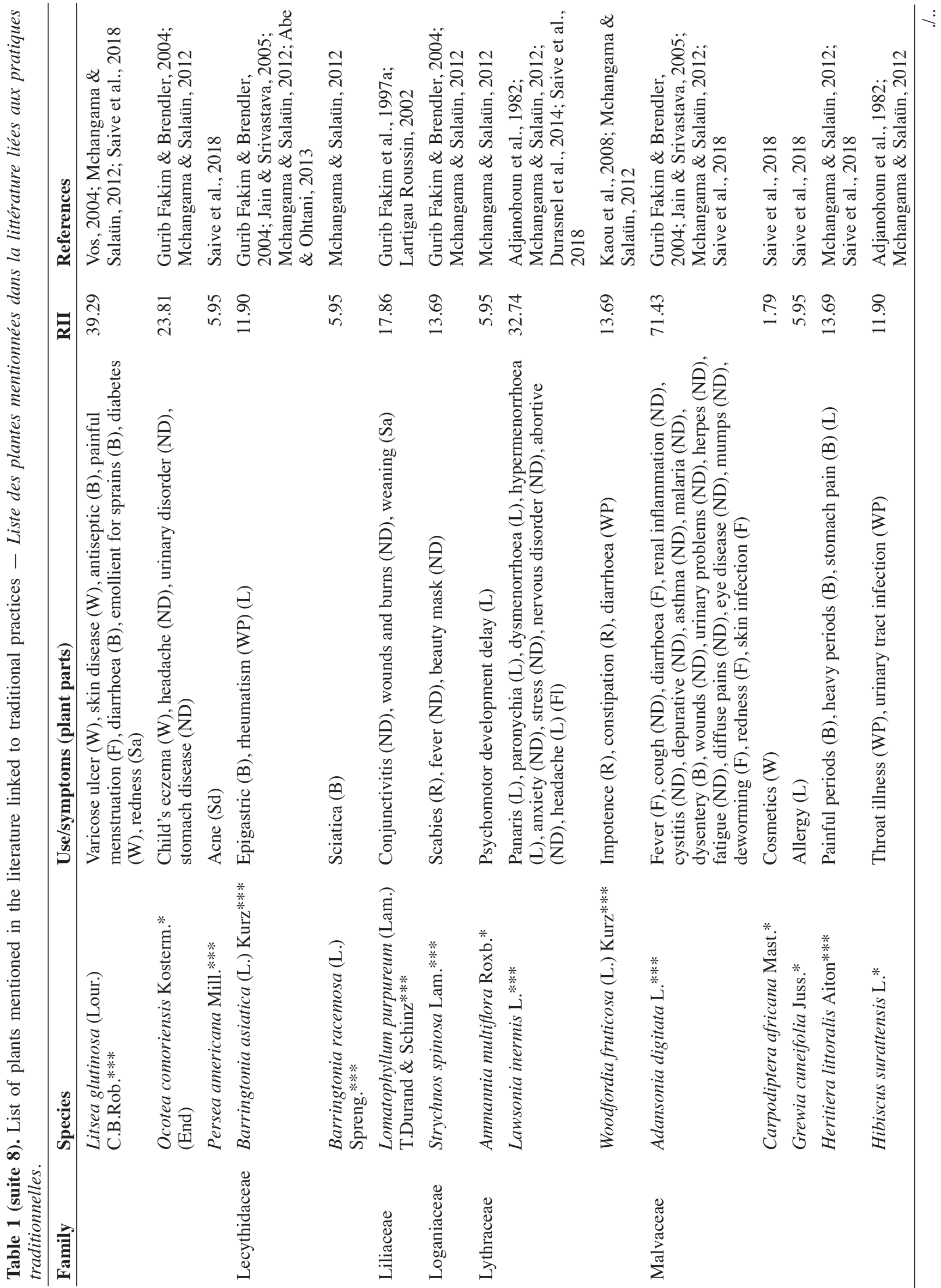




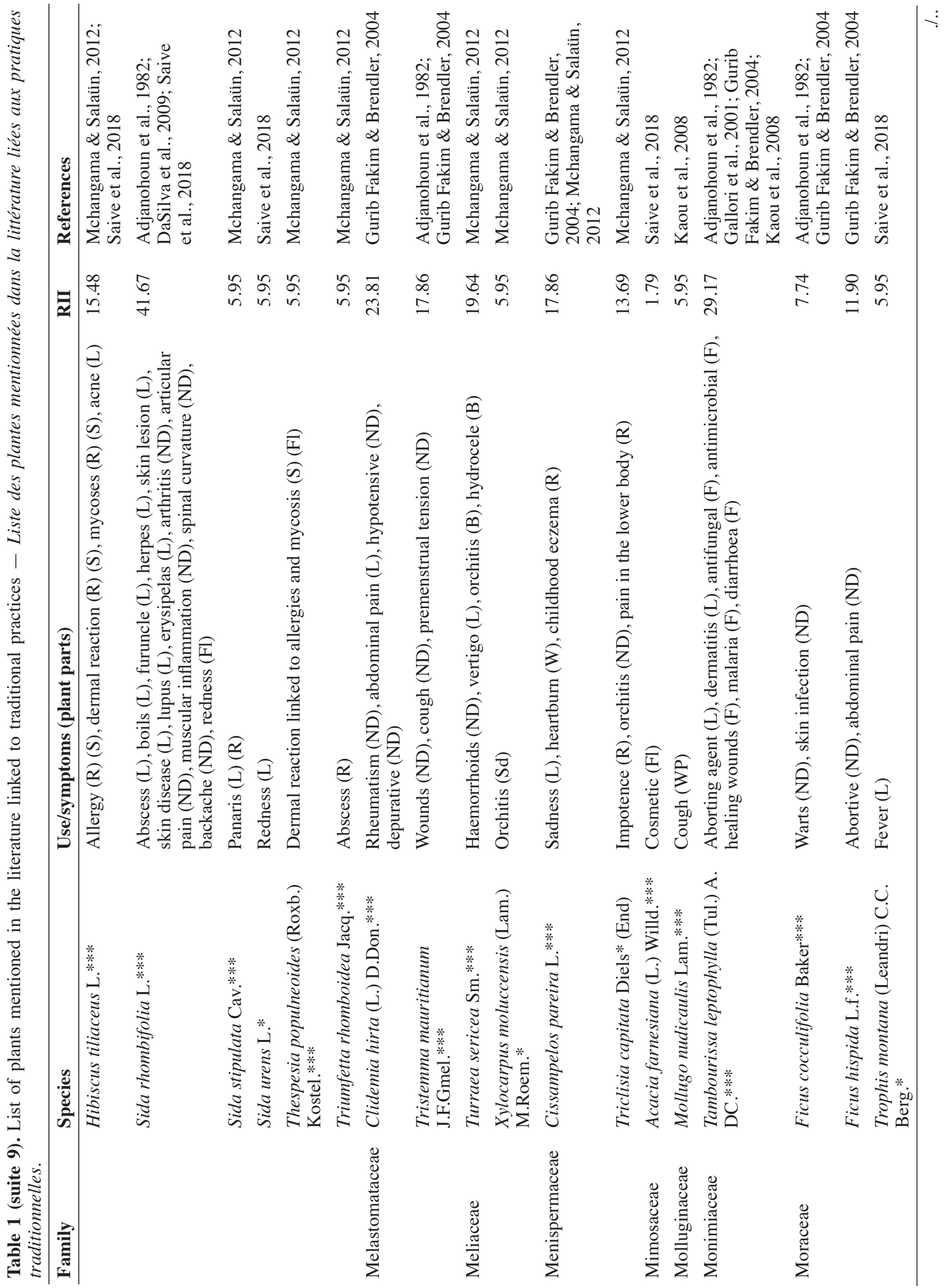




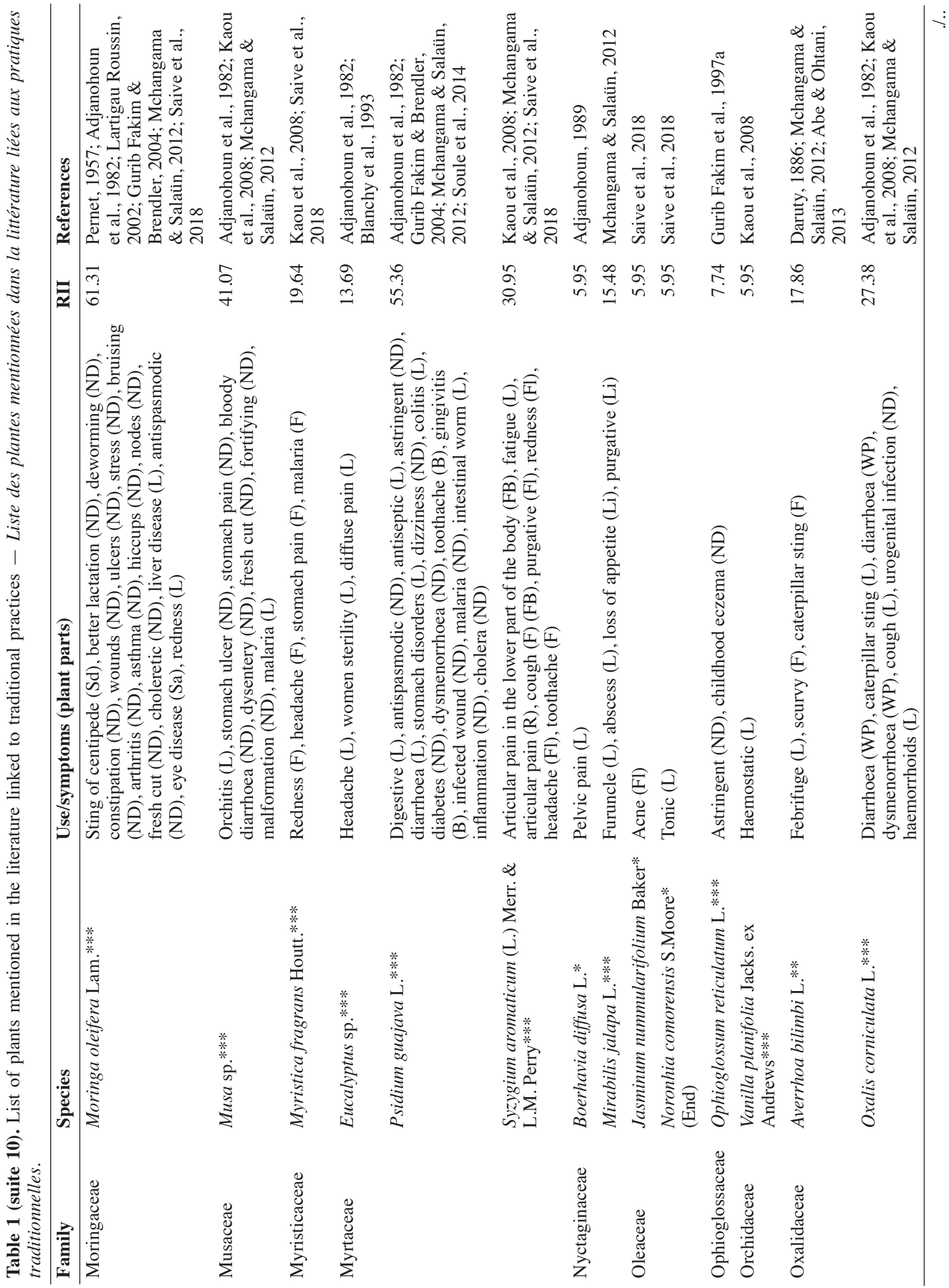




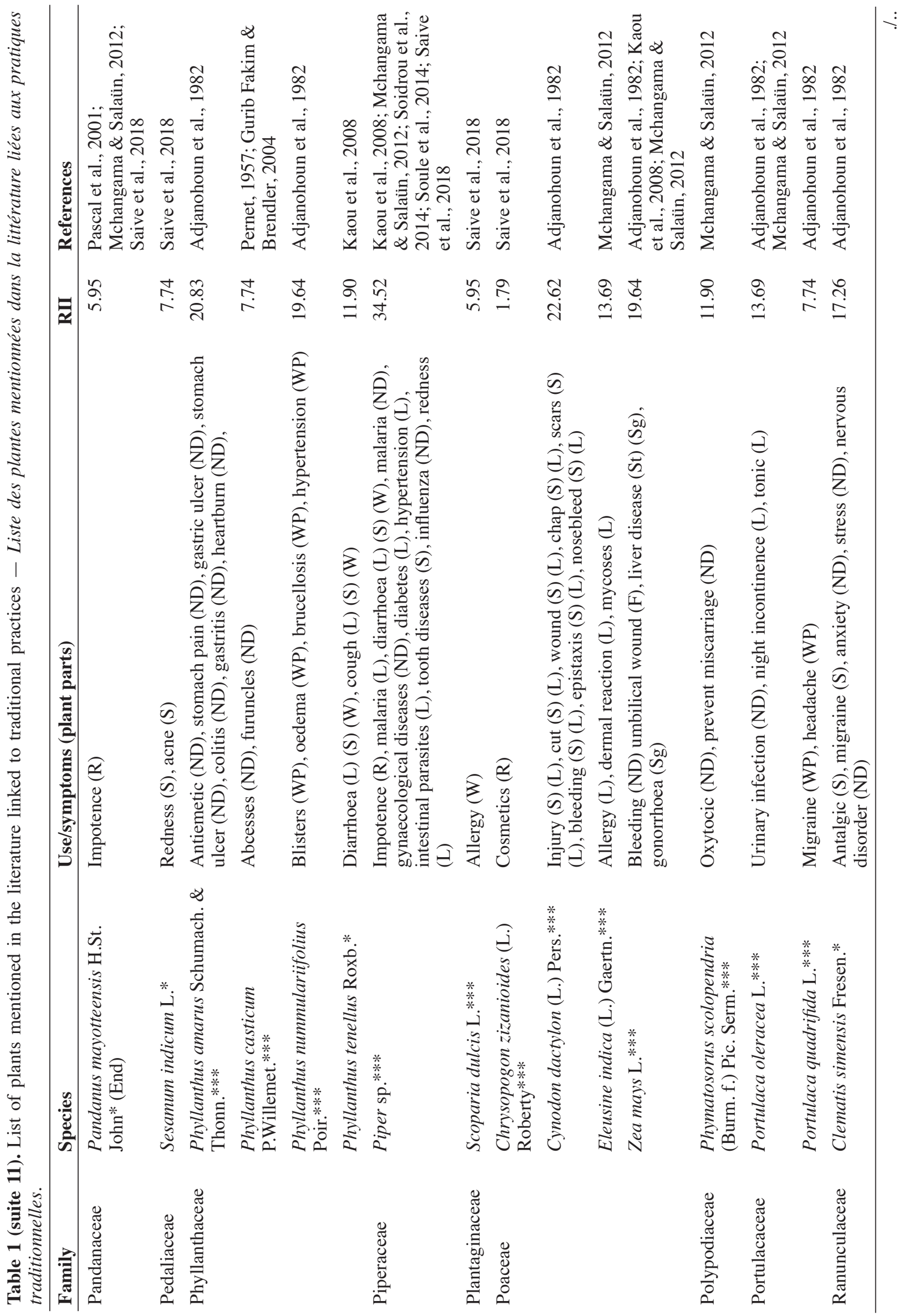




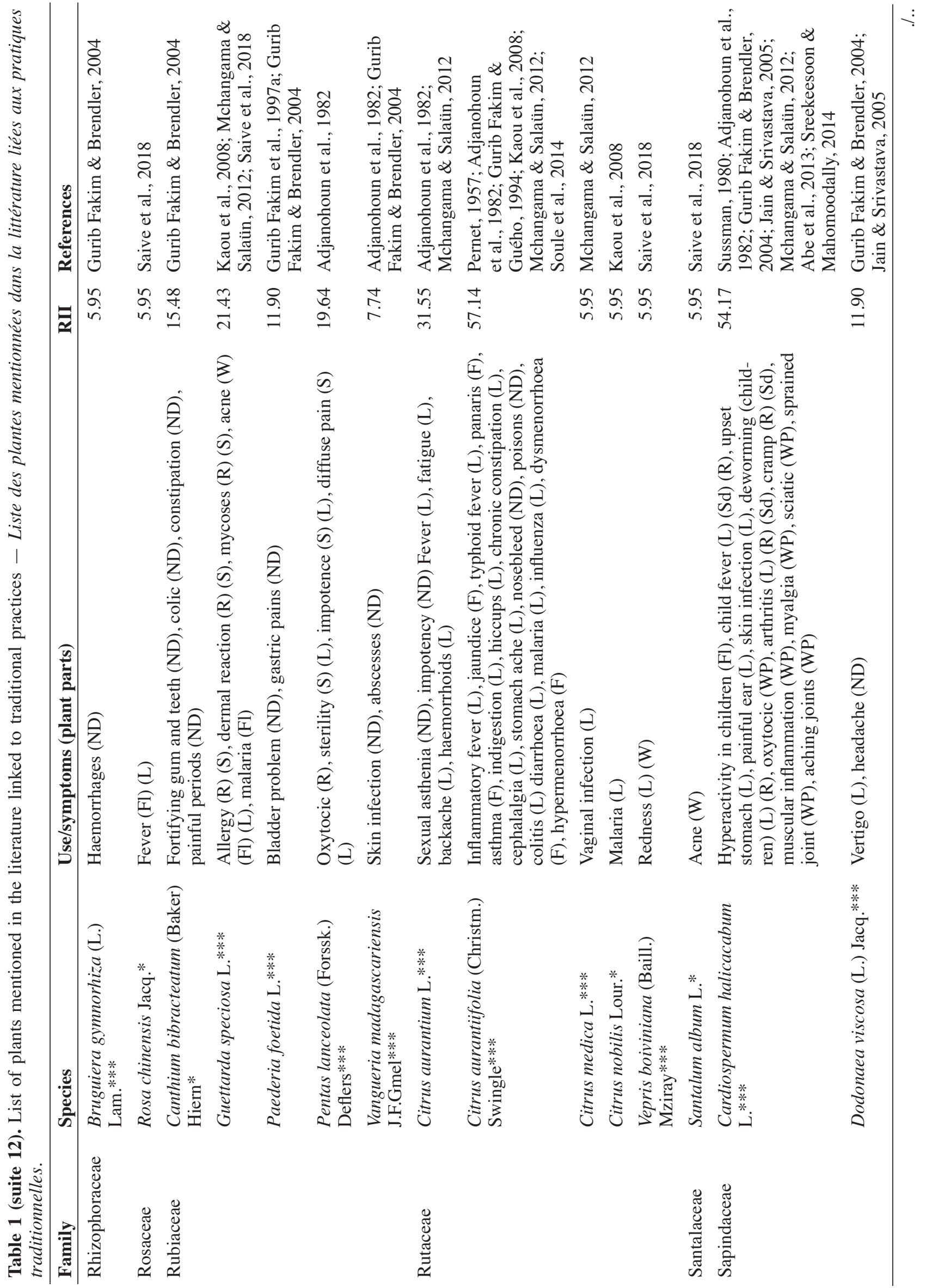




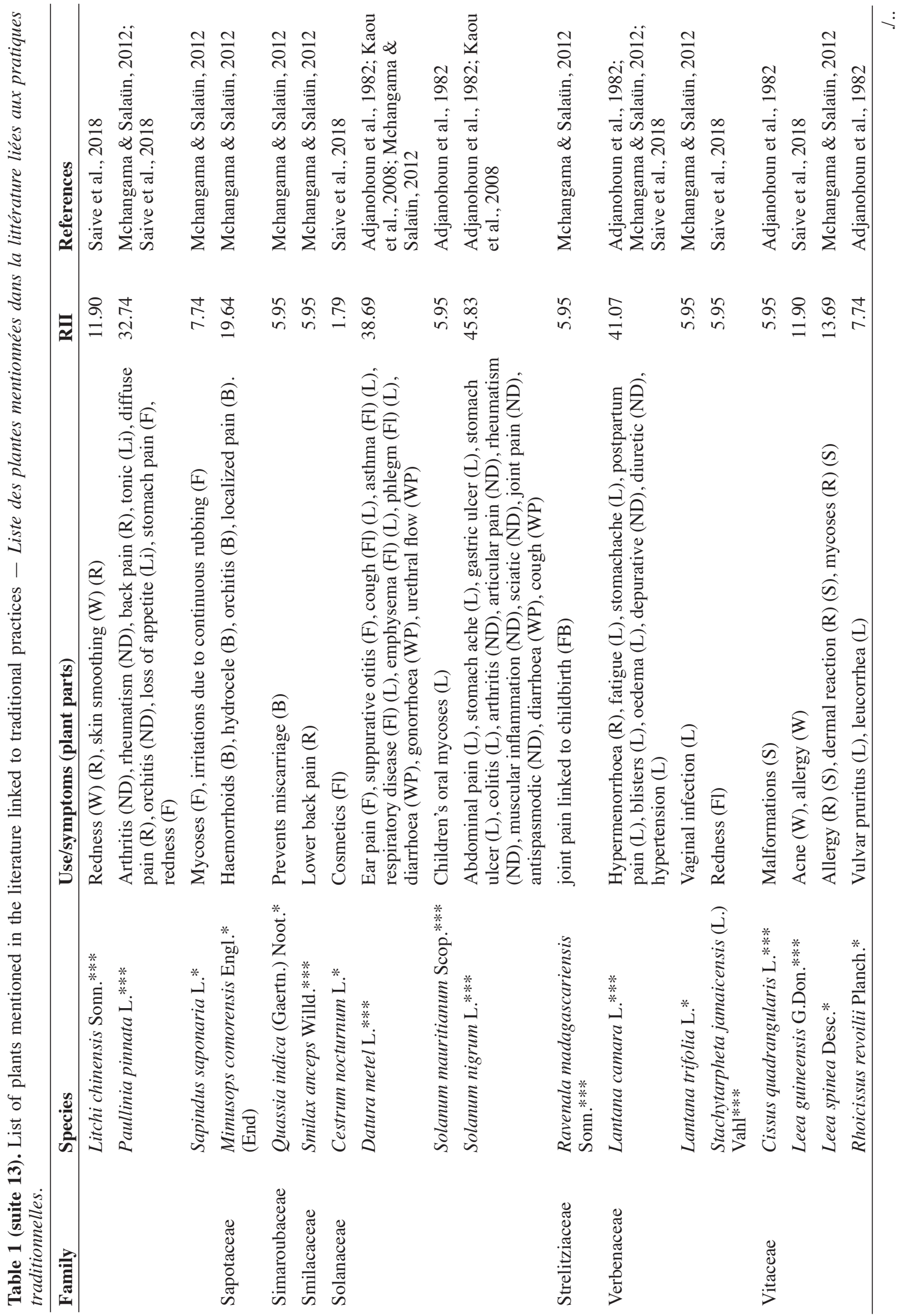




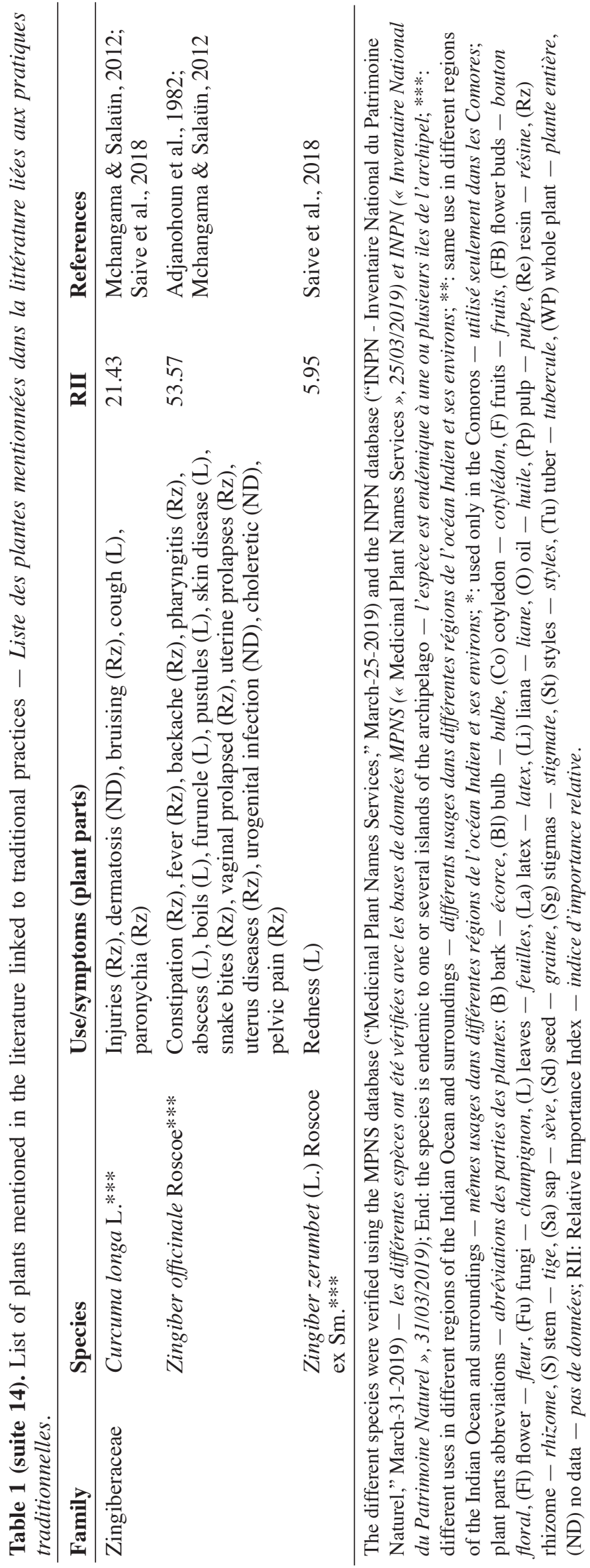

When it comes to the RNU, it seems that the main concern of the inhabitants of the Comoros archipelago are ailments linked with the following symptoms: diarrhoea $(\mathrm{RNU}=100)$, eczema and skin conditions $(\mathrm{RNU}=100)$, abdominal pain $(\mathrm{RNU}=86.84)$ and rheumatism $(\mathrm{RNU}=81.58)$. This information is interesting for further research in ethnopharmacology when focusing on diseases linked to these symptoms.

\section{TENDENCIES AND CULTURAL CONSENSUS}

Based on table 1, information on the consensus was also collated, leading to the following noteworthy points:

-56 species with one or more specific uses are known to be used only in the Comoros archipelago.Among these the one most mentioned is: Pandanus mayotteensis H.St.John. The dried roots of this species are ground together with the roots of Woodia fruticose (L.) Kurz, Desmodium ramosissimum G.Don., Triclisia capitate Baillon and Monanthotaxis glaucocarpa (Baill.) Verdc. The powder obtained is used as a decoction and drunk two times a day for seven days. This preparation is used to treat impotence (Pascal et al., 2001; Mchangama \& Salaün, 2012; Saive et al., 2018);

- Only 6 species are used for the same purpose in several islands of the Indian Ocean, thus showing an agreement on use between traditional healers. Among these, the ones most mentioned are: Averrhoa bilimbi L. and Acalypha lyallii Baker. In the Comoros archipelago, the fruits of A. bilimbi are used to treat itching; they are crushed with water and ashes to make a paste that is applied to the affected area (Daruty, 1886; Mchangama \& Salaün, 2012; Abe \& Ohtani, 2013). Acalypha lyallii is used as a leaf decoction to massage the body to treat rheumatism (Adjanohoun et al., 1982; Gurib Fakim \& Brendler, 2004; Seebaluck et al., 2015).

-145 species are used widely in the Indian Ocean and surroundings, including the Comoros archipelago islands, for many different ailments. Among these the one most mentioned is: Cardiospermum halicacabum L. Leaf decoctions are used to treat eczema, anasarca, ear diseases and wounds. Roots are used to treat dizziness, eye diseases, rheumatism and stiffness. Stems are used to manage fever in India. In the islands of the Indian Ocean, stems and roots are used as laxative and emetic as well as to treat cysts, bladder catharsis and gonorrhoea. The leaves 
are used to treat boils, rheumatisms, eczema and impetigo (Sussman, 1980; Adjanohoun et al., 1982; Gurib Fakim \& Brendler, 2004; Jain \& Srivastava, 2005; Mchangama \& Salaün, 2012; Abe \& Ohtani., 2013; Sreekeesoon \& Mahomoodally, 2014).

Throughout the classification in table $\mathbf{1}$, these 145 species are found the most frequently.

Even though $C$.halicacabum is the most often mentioned ( 7 sources), it does not have the widest variety of uses ( $\mathrm{RII}=54.17)$, ergo there is a certain consensus for the specific uses of this plant.

On the other hand, Plectranthus amboinicus (Lour.) Spreng. has fewer sources (6) but has many different uses (RII $=65.48)$, therefore pointing towards a higher versatility; e.g. a total of 21 traditional uses for this plant have been mentioned in the literature. In the Comoros archipelago, it is used as a cure for ailments ranging from a simple cough to colitis and flatulence, as well as rheumatism, malaria and furuncles. In Madagascar, leaves are added in meals as a food complement and are also used in decoctions or in fumigation to treat colds (Nicolas, 2012). In the Reunion Island, leaves of $P$. amboinicus are used in baths, infusions and for massage, to treat the symptoms caused by the chikungunya virus (fever, sore muscles and articulations) (Minker, 2007).

When it comes to similarities between different regions, the species Moringa oleifera Lam. (RII = 61.31) is used in the Comoros archipelago to treat asthma, hiccups and spasms among other uses (Table 1) (Adjanohoun et al., 1982; Gurib Fakim \& Brendler, 2004; Mchangama \& Salaün, 2012; Saive et al.,2018). In Mauritius and Seychelles, this species is linked to the treatment of throat related infections. For the anti-spasmodic effect of M. oleifera, people from Madagascar, Mauritius, Seychelles, as well as peoples from the Comoros archipelago tend to agree. As for the other uses mentioned in the Comoros archipelago, other places have their own use versatility: only inhabitants of Rodrigues and Seychelles use this species to treat high blood pressure, coughs and as an abortifacient, whereas in Madagascar, Mauritius and Rodrigues it is used to treat helminthiasis; in Mauritius, this plant is also used to treat nervous disorder, ear infections and fever and in Seychelles, this species is consumed as a refreshing drink (Pernet, 1957; Adjanohoun, 1983; Gurib Fakim \& Brendler, 2004).

In some cases, some plants are used in other islands of the Indian Ocean and surroundings and are part of the flora of the Comoros archipelago, but are not known to be part of the Comorian pharmacopoeia. Therefore, these species are not mentioned in table 1. E.g.: Cabucala erythrocarpa (Vatke) Markgr. is endemic to Madagascar and the Comoros archipelago.
In Madagascar, a bark decoction is drunk to treat viral hepatitis, malaria, stomach pain and diarrhoea. The bark is also used as a bitter ingredient in some alcoholic beverages, which are considered as strongly aphrodisiac. Leaves are used to treat skin infections and are consumed as decoctions to treat hypertension (Schmelzer \& Gurib Fakim, 2008). In the Reunion Island, an infusion of Hypercum lanceolatum Lam. yellow flowers is considered as refreshing, meaning that it helps manage fever as well as heartburn caused by the ingestion of hot and spicy food. This infusion is also considered helpful against urinary tract inflammation and will often be used as a depurative and to regulate menstruations (Lavergne, 1989). These plants are found in the Comoros archipelago; however, no use reports are mentioned there.

As expected, plants with fewer mentioned medicinal uses are more likely to be used the same way in different places, in comparison to plants with multiple medicinal uses. Acalypha lyallii is only used for rheumatism in the Indian Ocean, whereas B. pilosa is known for many uses in the Comoros archipelago but has even more uses in the surrounding islands. Out of the 207 different species mentioned in the present work, only $27 \%$ are used exclusively in the Comoros archipelago for a variety of purposes, $3 \%$ are used in the Comoros archipelago and in several islands and surroundings of the Indian Ocean for the same purposes and $70 \%$ are used in the Comoros archipelago and in other islands and surroundings of the Indian Ocean for comparable or different purposes. For the latter category, its size can be explained by the fact that many non-endemic species have been transported through the years and have diverse origins. Therefore, they might be used very differently in the different areas of the world where they are found.

When looking at different ethnobotanical studies carried out in the Maurice archipelago, Mauritius Island and Rodrigues Island are studied separately. On the other hand, most of the studies that were performed in the Comoros archipelago did not separate the different islands; in the present work however, separating the islands is important as some species are endemic to only one or two islands of the archipelago: e.g. Syzygium humblotii Labat \& Schatz and Eugenia choungiensis Byng \& N.Snow have been reported to be endemic to Mayotte. Syzygium tringiense Byng \& N.Snow is known to be endemic to the island of Anjouan (Byng et al., 2016) and Gyrostipula comorensis J.-F. Leroy was only endemic to Grande Comore and Mohéli but its endemicity has been widened to include Anjouan (Mouly, 2009). As these species are not found in all the Comorian islands, the archipelago should therefore not be studied as a whole but rather be investigated in its separate parts. When a clear separation between the geographic regions is made, the collected data have 
a higher impact when integrated into ethnobotanical indicators such as the informant agreement ratio.

Identification of species of interest for modern medicine is not the only reason to study the relationship the local people have with the flora that surrounds them. Other factors such as biodiversity management and protection (Nazarea, 1999), as well as the preservation of ancestral knowledge are two important objectives for ethnobotany studies, especially as traditional knowledge is mostly shared through oral tradition. Due to the growing access to modern medicine, the interest for traditional medicine tends to disappear; therefore, the number of traditional healers and their knowledge plummet. Ethnobotanists store plant specimens in herbaria, gather information on the uses of species and thereby preserve ancestral knowledge from extinction (Kaido et al., 1997).

The fact that plants have been used for centuries as medicines does not mean they are harmless. Their presumed innocuousness is based on hundreds of years of empirical observations (Fennell et al., 2004). Just as for modern medicines, there can be some deleterious effects. Due to the way traditional knowledge is transmitted, adverse effects are not always fully understood and serious poisoning due to traditional medicines is not uncommon. In South Africa, the estimated mortality due to traditional medicines ranges between 10,000 and 20,000 cases per year. This huge variability is due to a lack of precise data. Indeed, many cases of poisoning which are not recorded could possibly be linked to traditional medicine (Thomson, 2000; Popat et al., 2001).

As mentioned previously, some species are traditionally used for numerous diseases, which means that these species are under a strong anthropic pressure due to their biological value (Adjanohoun, 1983; Gurib Fakim, 1990; Lartigau Roussin, 2002; Gurib Fakim \& Brendler, 2004; Mchangama \& Salaün, 2012). If there is no management of these plants, there are chances that they will become extinct (Rasoanaivo, 2011).

When focusing on the case of the Comoros archipelago, it is important to remember that it came to exist through volcanic activity and therefore it has a very hilly landscape (Nougier et al., 1986), which is not ideal for crop production, even though the soil is rich and fertile (Clement et al., 2016). The discovery of medicinal values in plants in such places is an important opportunity to promote the development of these regions through the sustainable exploitation of interesting species. The high added value compensates for the lack of infrastructure for more traditional crops. Needless to say, the knowledge gathered from the traditional healers should be returned in one way or another to the population from which it originated (McManis, 2003; Rasoanaivo, 2011).

\section{CONCLUSIONS}

This review is an attempt to gather and examine numerous species used in the traditional pharmacopoeia of the Comoros Islands. Since the $19^{\text {th }}$ century, ethnobotany and ethnopharmacology have been an important part of the drug and cosmetic industry. Based on that affirmation, the study of biodiversity hotspots, especially the ones found on islands seems essential as they present a high concentration of different species in a defined area. In addition, the ethnobotanical work done in these places on Earth will allow us to maintain the knowledge developed by the people who have been working with these species for centuries and who have had the time to test the effectiveness of the remedies empirically. In the present work, 207 species were identified as part of the traditional pharmacopoeia of the Comoros archipelago. Some species are already known worldwide for their properties. However, many are still to be studied in order to validate their biological activities.

The specific uses for the different species mentioned herein can be compared to other databases and then using the previously mentioned tools, species that are more likely to be really effective and interesting for medicinal and cosmetic purposes can be identified and integrated into more hands-on studies. These differences and similarities will probably be of interest when this database is compared to data from around the world, giving more clues as to which species are likely to produce new cures.

\section{Acknowledgements}

The authors are grateful to the University of Liège (Belgium) for allowing us to gain access to all the information required for an exhaustive study of the subject.

\section{Bibliography}

Abdurazag A. et al., 2003. Medicinal plants and their utilization. Trieste, Italy: ICS-UNIDO.

Abe R. \& Ohtani K., 2013. An ethnobotanical study of medicinal plants and traditional therapies on Batan Island, the Philippines. J. Ethnopharmacol., 145(2), 554-565, doi.org/10.1016/j.jep.2012.11.029

Adjanohoun E., 1983. Contribution aux études ethnobotaniques et floristiques à Maurice (Iles Maurice et Rodrigues). Paris : Agence de Coopération Culturelle et Technique.

Adjanohoun E., 1989. Contribution aux études ethnobotaniques et floristiques en République populaire 
du Bénin. Paris : Agence de Coopération Culturelle et Technique.

Adjanohoun E., Aké Assi L. \& Ahmed A., 1982. Contribution aux études ethnobotaniques et floristiques aux Comores. Paris : Agence de Coopération Culturelle et Technique.

Barthelat F. \& Boullet V., 2005. Flore vasculaire. In : Mayotte. Biodiversité et évaluation patrimoniale. Contribution à la mise en auvre de l'inventaire ZNIEFF. Mascarin, La Réunion: Conservatoire Botanique National de Mascarin ; Mayotte : DAF, 107199.

Barthelat F. \& Viscardi G., 2012. Flore menacée de l'île de Mayotte: importance patrimoniale et enjeux de conservation. Rev. Écologie, suppl. 11, 15-27.

Bartolome A.P., Villaseñor I.M. \& Yang W.-C., 2013. Bidens pilosa L. (Asteraceae): botanical properties, traditional uses, phytochemistry, and pharmacology. Evidence-based Complementary Altern. Med., 2013, 1-51, doi.org/10.1155/2013/340215

Bennett B.C.\& Prance G.T., 2000. Introduced plants in the indigenous pharmacopoeia of northern South America. Econ. Bot., 54(1), 90-102, doi.org/10.1007/bf02866603

Blanchy S. et al., 1993. Thérapies traditionnelles aux Comores. Cah. Sci. Humaines, 29(4), 763-790.

Boullet V., 2016. Index de la flore vasculaire de Mayotte (Trachéophytes): statuts, menaces et protections. Version 2016.1 (mise à jour du 16 décembre 2016). Mayotte, Comores : Conservatoire Botanique National de Mascarin, antenne de Mayotte-Coconi, http:// floremaore.cbnm.org, (04/12/2017).

Bouloc P., 2006. Le chanvre industriel : production et utilisations. Paris : Éditions France Agricole.

Brownstein M.J., 1993. A brief history of opiates, opioid peptides, and opioid receptors. Proc. Natl. Acad. Sci. U.S.A., 90(12), 5391-5393, doi.org/10.1073/ pnas.90.12.5391

Byng J.W., Barthelat F., Snow N. \& Bernardini B., 2016. Revision of Eugenia and Syzygium (Myrtaceae) from the Comoros archipelago. Phytotaxa, 252(3), 163, doi. org/10.11646/phytotaxa.252.3.1

Cartier M., 1994. À propos de l'histoire du coton en Chine. Approche technologique, économique et sociale. Études Chinoises, 13(1), 417-435, doi.org/10.3406/ etchi.1994.1220

Clement B. et al., 2016. A spatially explicit assessment of climate change vulnerability in the agricultural sector of the Union of the Comoros. CCAFS Working Paper no. 186. Copenhagen: CGIAR Research Program on Climate Change, Agriculture and Food Security (CCAFS).

Daruty C., 1886. Plantes médicinales de l'île Maurice et des pays intertropicaux. Port-Louis, Maurice : General Steam Printing Company.

DaSilva E.J., Krishnapillai M.V \& D’Ayala P.G., 2009. Biocultural diversity and medicine. In: Doelle H.W., Rokem S.
\& Berovic M., eds. Biotechnology. Vol. 11: Fundamentals in biotechnology. Oxford, UK: EOLSS Publishers/Unesco.

Dugé de Bernonville T. et al., 2015. Phytochemical genomics of the Madagascar periwinkle: unravelling the last twists of the alkaloid engine. Phytochemistry, 113, 9-23, doi. org/10.1016/j.phytochem.2014.07.023

Durasnel P.et al., 2014. Intoxications graves lors de traitements traditionnels par les plantes à Mayotte. Bull. Soc. Pathol. Exot., 107(5), 306-311, doi.org/10.1007/s13149-0140400-7

Ekoumou C., 2003. Étude phytochimique et pharmacologique de 5 recettes traditionnelles utilisées dans le traitement des infections urinaires et de la cystite. Thèse de doctorat : Université de Bamako (Mali).

El-Hilaly J., Hmammouchi M. \& Lyoussi B., 2003. Ethnobotanical studies and economic evaluation of medicinal plants in Taounate province (Northern Morocco). J. Ethnopharmacol., 86(2-3), 149-158, https:// doi.org/10.1016/s0378-8741(03)00012-6

Farnsworth N.R., 1966. Biological and phytochemical screening of plants. J. Pharm. Sci., 55(3), 225-276, doi. org/10.1002/jps.2600550302

Farnsworth N.R., 1994. Ethnopharmacology and drug development. In: Chadwick D.J. \& Marsh J., eds. Ciba Foundation Symposium 185, Ethnobotany and the search for new drugs. Indianapolis, IN, USA : Ciba Foundation, 42-59.

Fennell C.W. et al., 2004. Assessing African medicinal plants for efficacy and safety: pharmacological screening and toxicology. J. Ethnopharmacol., 94(2-3), 205-217, doi. org/10.1016/j.jep.2004.05.012

Fortin H. et al., 2002. In vitro antiviral activity of thirty-six plants from La Réunion Island. Fitoterapia, 73(4), 346350, doi.org/10.1016/s0367-326x(02)00080-1

Gallori S. et al., 2001. Identification of volatile constituents of Tambourissa leptophylla. Planta Med., 67(3), 290-292, doi.org/10.1055/s-2001-12001

Godara P., Dulara B. \& Barwar N., 2015. Multidimensional approach of endangered ayurvedic plant Leptadenia reticulata: a review. Int. J. Appl. Sci. Eng. Res., 4(4), 531543.

Gurib Fakim A., 1990. Medicinal plants of Mauritius. Int. J. Crude Drug Res., 28(4), 297-308, doi. org/10.3109/13880209009082837

Gurib Fakim A., 2002. Mauritius through its medicinal plants: towards a better understanding of medicinal plants of the Indian Ocean Islands. Vacoas-Phoenix, Ile Maurice: Éditions Le Printemps.

Gurib Fakim A., 2003. Illustrated guide to the flora of Mauritius $\&$ the Indian Ocean Islands. Ebène, Ile Maurice : Centre de Phytothérapie et de Recherche.

Gurib Fakim A., 2011. Small island developing states of the Indian Ocean: towards an action plan for medicinal plants. Asian Biotechnol. Dev. Rev., 13(3), 1-5.

Gurib Fakim A. \& Guého J., 1994. Plantes médicinales de l'île Rodrigues : pharmacognosie, phytochimie et étude 
comparative des données ethnobotaniques avec celles des autres îles du sud ouest de l'Océan indien. RoseHill, Ile Maurice : Édition de l'Océan indien ; Réduit, Ile Maurice : Université de Maurice.

Gurib Fakim A., Guého J. \& Bissoondoyal M.D., 1997a. Plantes médicinales de Maurice. Vol.3. Pharmacognosie, phytochimie et étude comparative des données ethnobotaniques avec celles des autres îles du sud ouest de l'Océan indien. Rose-Hill, Ile Maurice: Édition de l'Océan indien ; Réduit, Ile Maurice: Université de Maurice.

Gurib Fakim A., Gueho J. \& Sewraj-Bissoondoyal M., 1997b. The medicinal plants of Mauritius-part 1. Int. J. Pharmacogn., 35(4), 237-254.

Gurib Fakim A. \& Guého J., 1999. Natural toxins and poisonous plants of Mauritius. Vacoas-Phoenix, Ile Maurice: Éditions Le Printemps

Gurib Fakim A. \& Brendler T., 2004. Medicinal and aromatic plants of Indian Ocean Islands: Madagascar, Comoros, Seychelles and Mascarenes. Stuttgart, Germany: Medpharm Scientific Publishers.

Hashim P. et al., 2011. Triterpene composition and bioactivities of Centella asiatica. Molecules, 16(2), 1310-1322, doi.org/10.3390/molecules 16021310

Hassane S.O.S. et al., 2011. Composition chimique et bioactivité des huiles essentielles de deux provenances d'Ocimum canum S. de l'île de la Grande Comore. Phytothérapie, 9, 18-24, doi.org/10.1007/s10298-0100602-5

Hassani M.S. et al., 2012. Chemical composition and antimicrobial activity of Plectranthus amboinicus (Lour) Spring. essential oil from archipelago of Comoros. J. Essent. Oil-Bearing Plants, 15(4), 637-644, doi.org/1 0.1080/0972060x.2012.10644098

Heinrich M., 2015. Ethnopharmacology: a short history of a multidisciplinary field of research. In: Ethnopharmacology. Chichester, UK: John Wiley \& Sons, Ltd, 1-10.

Heitzman M.E.etal.,2005.Ethnobotany,phytochemistry and pharmacology of Uncaria (Rubiaceae). Phytochemistry, 66(1), 5-29, doi.org/10.1016/j.phytochem.2004.10.022

Hoffman B., Gallaher T. \& Gallaher T., 2007. Importance indices in ethnobotany. Ethnobot. Res. Appl., 5, 201-218, doi.org/10.17348/era.5.0.201-218

Holmstedt B., 1991. Historical perspective and future of ethnopharmacology. J. Ethnopharmacol., 32(1-3), 7-24, doi.org/10.1016/0378-8741(91)90099-y

INPN (Inventaire National du Patrimoine Naturel). https:// inpn.mnhn.fr/accueil/index, (31/03/2019).

Jain S.K. \& Srivastava S., 2005. Traditional uses of some Indian plants among islanders of the Indian Ocean. Indian J. Traditional Knowledge, 4(4), 345-357.

Jonville M.C. et al., 2008. Screening of medicinal plants from Reunion Island for antimalarial and cytotoxic activity. J. Ethnopharmacol., 120(3), 382-386, doi. org/10.1016/j.jep.2008.09.005.
Kaido T.L., Veale D.J.H., Havlik I. \& Rama D.B.K., 1997. Preliminary screening of plants used in South Africa as traditional herbal remedies during pregnancy and labour. J. Ethnopharmacol., 55(3), 185-191, doi.org/10.1016/ s0378-8741(96)01499-7

Kaou A.M.et al., 2008. Antimalarial activity of crude extracts from nine African medicinal plants. J. Ethnopharmacol., 116(1), 74-83, doi.org/10.1016/j.jep.2007.11.001

Katiyar C., Gupta A., Kanjilal S. \& Katiyar S., 2012. Drug discovery from plant sources: an integrated approach. Ауи, 33(1), 10-9, doi.org/10.4103/0974-8520.100295

Kelly K., 2009. The history of medicine. Early civilizations: prehistoric times to 500 C.E. New York, NY, USA: Facts On File.

Lartigau Roussin C., 2002. Une approche de la médecine traditionnelle à Mayotte : des plantes en question. Bull. bat-Hist.\& Géo Mayotte, 6, 38-43.

Lavergne R., 1989. Étude ethnobotanique des plantes utilisées dans la pharmacopée traditionnelle à la Réunion. Paris : ACCT.

Maregesi S.M., Nyamwisenda N.T., Mwangomo D. \& Kidukuli A., 2013. In vitro antimicrobial activity and determination of essential metal and ash value contents of Trichodesma zeylanicum. IJRPP, 2(3), 417-424.

Mchangama M. \& Salaün P., 2012. Recueil d'une pharmacopée à Mayotte. Études Océan Indien, 48, doi. org/10.4000/oceanindien. 1770

McManis C.R., 2003. Intellectual property, genetic resources and traditional knowledge protection: thinking globally, acting locally. Cardozo J. Int. Comparative Law, 11, 547.

Medicinal Plant Names Services, 2019. Version 6, http:// www.kew.org/mpns, (25/03/2019).

Mhame P.P., 2004. The role of traditional knowledge in the national economy: traditional medicine in Tanzania. In: Twarog S. \& Kapoor P., eds. Protecting and promoting traditional knowledge: systems, national experiences and international dimensions. New York, NY, USA: United Nations, 17-20.

Minker C., 2007. La flore médicinale réunionnaise et le chikungunya. Strasbourg, France: Université Louis Pasteur .

Morat P. \& Lowry P.P., 1997. Floristic richness in the AfricaMadagascar region: a brief history and prospective. Adansonia, 19(1), 101-115.

Mouly A., 2009. The endemic Rubiaceae canopy trees of the Comorian Archipelago: floristic affinities in the Indian Ocean and taxonomy. Adansonia, 31(1), 197-206.

Nazarea V.D., 1999. Ethnoecology: situated knowledgel located lives. Tucson, AZ, USA: University of Arizona Press.

Nicolas J.-P., 2012. Plantes médicinales $d u$ Nord de Madagascar: ethnobotanique Antakarana et informations scientifiques. Brasparts, Madagascar: Jardins du monde.

Nougier J., Cantagrel J.M. \& Karche J.P., 1986. The Comores archipelago in the western Indian Ocean: 
volcanology, geochronology and geodynamic setting. J. Afr. Earth Sci., 5(2), 135-145, doi.org/10.1016/08995362(86) $90003-5$

OMM, 2018. Organisation Météorologique Mondiale, www.wmo.int/pages/index_fr.html, (20/08/2018).

Panara K. et al., 2016. Importance of Alangium salviifolium and its pharmacological update. Eur. J. Med. Plants, 12(124), 1-15.

Pardo de Santayana M., 2003. Las plantas en la cultura tradicional de la antigua Merindad de Campoo. Madrid: Universidad Autónoma de Madrid.

Pascal O., 2002. Plantes et forêts de Mayotte. Paris : Muséum national d'Histoire naturelle.

Pascal O., Labat J.-N., Pignal M. \& Soumille O., 2001. Diversité, affinités phytogéographiques et origines présumées de la flore de Mayotte (Archipel des Comores). Syst. Geogr. Plants, 71(2), 1101, doi. org/10.2307/3668743

Pernet R., 1957. Les plantes médicinales malgaches. Catalogue de nos connaissances chimiques et pharmacologiques. Mem. Inst. Sci. Madagascar, ser. B, 8, 1-143.

Popat A. et al., 2001. The toxicity of Callilepis laureola, a South African traditional herbal medicine. Clin. Biochem., 34(3), 229-236, doi.org/10.1016/s00099120(01)00219-3

Poullain C., Girard-Valenciennes E. \& Smadja J., 2004. Plants from Reunion island: evaluation of their free radical scavenging and antioxidant activities. J. Ethnopharmacol., 95(1), 19-26, doi.org/10.1016/j. jep.2004.05.023

Pourchez L., 2011. Savoirs des femmes. Médecine traditionnelle et nature (Maurice, Rodrigues, La Réunion). Tribunes Santé,44(3), 51-71, doi.org/10.3917/ seve.044.0051

Prance G.T., Balée W., Boom B.M. \& Carneiro R.L., 1987. Quantitative ethnobotany and the case for conservation in ammonia. Conserv. Biol., 1(4), 296-310, doi. org/10.1111/j.1523-1739.1987.tb00050.x

Quod J.-P., Naim O. \& Abdourazi F., 2000. The Comoros archipelago. In: Sheppard C.R.C., ed. Seas at the millennium: an environmental evaluation: 2. Regional chapters: The Indian Ocean to the Pacific. Amsterdam, The Netherlands: Elsevier Science.

Rabearivony A.D. et al., 2015. Ethnobotanical study of the medicinal plants known by men in Ambalabe, Madagascar. Ethnobot. Res. Appl., 14(0), 123, doi. org/10.17348/era.14.0.123-138

Rakotoarivelo N.H., Sukkho T. \& Trisonthi C., 2015. Medicinal plants used to treat the most frequent diseases encountered in Ambalabe rural community, Eastern Madagascar. J. Ethnobiol. Ethnomed., 11(1), 68, doi. org/10.1186/s13002-015-0050-2

Rakotoniaina E.N. et al., 2018. Insights into an endemic medicinal plant species of Madagascar and Comoros: the case of Famelona (Chrysophyllum boivinianum (Pierre) Baehni, Sapotaceae family). South Afr. J. Bot., 117, 110-118, doi.org/10.1016/j. sajb.2018.05.010

Randriamiharisoa M.N. et al., 2015. Medicinal plants sold in the markets of Antananarivo, Madagascar. J. Ethnobiol. Ethnomed., 11(1), 60, doi.org/10.1186/s13002-0150046-y

Rangel J.A.O., 2009. Synergistic HIV/AIDS and/or immune disease phyto-nutraceutical composition. United States Patent Appl. Publ. within the TVPP US20060470842, 7 September 2006.

Rasoanaivo P., 2011. Drugs and phytomedicines in Indian Ocean and Madagascar: issues in research, policy and public health. Asian Biotechnol. Dev. Rev., 13(3), 7-25.

Razafindraibe M. et al., 2013. Medicinal plants used by women from Agnalazaha littoral forest (Southeastern Madagascar). J. Ethnobiol. Ethnomed., 9(1), 73, doi. org/10.1186/1746-4269-9-73

Saive M., Frederich M. \& Fauconnier M.-L., 2018. Plants used in traditional medicine and cosmetics in Mayotte Island (France): an ethnobotanical study. Indian $J$. Traditional Knowl., 17(4).

Samoisy A.K. \& Mahomoodally M.F., 2015. Ethnopharmacological analysis of medicinal plants used against non-communicable diseases in Rodrigues Island, Indian Ocean. J. Ethnopharmacol., 173, 20-38, doi. org/10.1016/j.jep.2015.06.036

Schmelzer G.H. \& Gurib-Fakim A., eds., 2008. Ressources végétales de l'Afrique tropicale 11(1). Plantes médicinales 1. Fondation PROTA; Leiden, PaysBas: Backhuys Publishers ; Wageningen, Pays-Bas : CTA.

Seebaluck R., Gurib Fakim A. \& Mahomoodally F., 2015. Medicinal plants from the genus Acalypha (Euphorbiaceae)-A review of their ethnopharmacology and phytochemistry. J. Ethnopharmacol., 159, 137-157, doi.org/10.1016/j.jep.2014.10.040

Singh Tanwer B. \& Vijayvergia R., 2014. Biological evaluation of Alangium salviifolium (L. F.) Wangerin. J. Chem. Pharm. Res., 6(12), 611-618.

Soidrou S.H. et al., 2013. Ethnopharmacoligical investigation of five plants used in Comorian folkloric medicine. Int. J. Phytopharm., 4(4), 230-236.

Soidrou S.H. et al., 2014. Immunomodulatory activity of phenolic fraction from Piper borbonense and Cassytha filiformis growing in Comoros Islands. In: Gupta Bhowon M., Jhaumeer-Laulloo S., Li Kam Wah H. \& Ramasami P., eds. Chemistry: the key to our sustainable future, Dordrecht, The Netherlands: Springer, 105-112, doi.org/10.1007/978-94-007-7389-9_7

Soule H.H. et al., 2014. Ethnopharmacological investigation of four plants used as medicinal in Ngazidja island. Int . J. Phytopharm., 5(6), 416-422.

Sreekeesoon D.P. \& Mahomoodally M.F., 2014. Ethnopharmacological analysis of medicinal plants and animals used in the treatment and management of pain 
in Mauritius. J. Ethnopharmacol., 157, 181-200, doi. org/10.1016/j.jep.2014.09.030

Sussman L.K., 1980. Herbal medicine on Mauritius. J. Ethnopharmacol., 2(3), 259-278, doi.org/10.1016/ s0378-8741(80)81005-1

Tardío J. \& Pardo de Santayana M., 2008. Cultural importance indices: a comparative analysis based on the useful wild plants of southern Cantabria (northern Spain). Econ. Bot., 62(1), 24-39, doi.org/10.1007/ s12231-007-9004-5

Tatayah V., 2011. Status of conservation of native medicinal plants of Mauritius and Rodrigues. Asian Biotechnol. Dev. Rev., 13(3), 85-108.

Terrac M.L., 1947. Contribution à l'étude des plantes médicinales de Madagascar, de la Réunion et de l'île Maurice. Paris : Imprimerie polyglotte Vuibert

Thomson S., 2000. Traditional African medicine: genocide, and ethnopiracy against the African people. Report to the South African Medicines Control Council. Knysna, South Africa: Gaia Research Institute.
Tiong S. et al., 2013. Antidiabetic and antioxidant properties of alkaloids from Catharanthus roseus (L.) G.Don. Molecules, 18(8), 9770-9784, doi.org/10.3390/ molecules 18089770

Trotter R.T. \& Logan M.H., 1986. Informant consensus: a new approach for identifying potentially effective medicinal plants. In: Etkin N.L., ed. Plants in indegenous medicine and diet: biobehavioral approaches. New York, NY, USA: Routledge, 91-112, doi.org/10.4324/9781315060385-6

UNCTAD, 2011. Guide de l'investissement aux Comores. Opportunités et conditions 2011. New York, NY, USA; Genève, Suisse : Nations Unies.

Vos P., 2004. Case studies on the status of invasive woody plant species in the Western Indian Ocean: 2. The Comoros Archipelago (Union of the Comoros and Mayotte). Forest Health \& Biosecurity Working Paper. Roma: FAO.

(100 ref.) 